Revue belge de géographie

$1-2 \mid 2012$

Inaugural issue

\title{
Symbols in political centres. Where they are and what they mean
}

Les symboles dans les centres politiques : localisation et signification

\section{Herman van der Wusten}

\section{(2) OpenEdition}

Journals

\section{Electronic version}

URL: http://journals.openedition.org/belgeo/6110

DOI: 10.4000/belgeo.6110

ISSN: 2294-9135

\section{Publisher:}

National Committee of Geography of Belgium, Société Royale Belge de Géographie

\section{Electronic reference}

Herman van der Wusten, «Symbols in political centres. Where they are and what they mean », Belgeo [Online], 1-2 | 2012, Online since 15 December 2012, connection on 19 April 2019. URL : http:// journals.openedition.org/belgeo/6110; DOI : 10.4000/belgeo.6110

This text was automatically generated on 19 April 2019

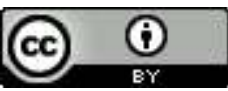

Belgeo est mis à disposition selon les termes de la licence Creative Commons Attribution 4.0 International. 


\title{
Symbols in political centres. Where they are and what they mean
}

Les symboles dans les centres politiques : localisation et signification

\author{
Herman van der Wusten
}

\section{Political centre formation}

1 Where human beings come together, politics emerges. Politics comprises all efforts directed at collective goal attainment, anything from the preparation of collective harvesting to the smooth operation of a voluntary association. Differentiated, complex societies can not cope without an extensive set of distinct regulatory institutions directed at societal goal attainment. The acceptance of such political institutions by those who are regulated and by outsiders is facilitated by some sense of common purpose, loyalty with the way they operate and approval of the pattern of their outcomes in the long run. These institutions need sufficient power assets to enforce their decisions, also against outsiders (this particularly follows Parsons, 1971; also Claval, 2010).

2 Public authorities in charge of these institutions tend to be concentrated in certain places and to stretch their authority across a certain spatial range thus delimiting their territory. In this paper I focus on these centres (a systematic attempt to model the emergence of political units from their centres is Rokkan, 2000, in particular pp. 138-155). In many cases the political unit was initially founded in these centres that then acted as the basis for shaping a societal collectivity (e.g. Ile de la Cité in Paris), in other cases they were selected afterwards as a political expression of a societal collectivity once it had been formed (e.g. Capitol Hill - Mall - White House in Washington D.C.).

3 The political institutions and public authorities accommodated in political centres are always provisional however emphatic they tend to be portrayed as longstanding and forever after, but the pace and types of change differ. Political centre formation is therefore never ending. Recurrent piecemeal adaptations to shifting circumstances and internal dynamics alternate with wholesale transformations where public authority stays 
in the same place but changes in kind (in many revolutions but not always, e.g. the Bolcheviks, Ataturk) or where the location of public authority changes decisively (quite some political authorities have in recent decades shifted to new capital cities, mostly for reasons of presumed internal development dynamics (Gordon, 2006).

4 The place-making of political centres is to an important extent driven by the intention to resolve straightforward material functional problems to allow the social action required as a public authority (Bertrand, 1974): office space requirements for personnel, meeting rooms to gather for internal consultations and to see visitors, protected spaces for the uninterrupted practice of ruling behaviour or for the necessarily secluded circumstances under which public authorities have to operate much of the time, generally accessible spaces for the conduct of public affairs where it is done in the open. But political centres are also loaded with meaning, mostly intentionally sometimes not. The signs used for that purpose - they are culturally functional - express and underline the strength of the public authority and the nature of that strength.

5 As states are currently the most salient carriers of public authorities, interest in these questions tends to concentrate on the political centres nearly universally situated within their capital cities. This only causes confusion in a very small number of cases. Apart from the political centres of national states, lower tier government units also have them. The states within a federal construction obviously make extra efforts to express their importance, the US emphasizing their commonality by emulating the construction of a capitol in most state capitals after the federation's unity had been severely put to the test in a civil war. At the supranational level international organizations have their statutory places of residence where secretariats, executive buildings, convention halls etc. in several instances show the typical assets of global or macro-regional political centres (Van der Wusten, 2012). All these centres and capitals, apart from material functional considerations have been designed and function additionally as symbols of the political institutions for whom they were constructed ("Washington says ...").

In the remainder of this paper I first elaborate on the ways signs and symbols work (2). In the following section this is applied to the material environment in which public authority operates (3). Subsequently I use these arguments to discuss some studies of the spatio-temporal variation of symbolic content intentionally made in the national political centres and capital cities of Europe's states (4). Finally I add some promising directions for future research on these issues (5).

\section{Signs and symbols: conceptual issues}

7 Taking the localized presence of political authority for granted, I focus here on the support of that authority by elements of the material context in which it operates. Long corridors, high chairs, appropriate systems of lighting, outsized office spaces create a solemn atmosphere in which hierarchically ordered relationships find a "natural" environment. All such elements can thus also be interpreted as signs underlining authority. Signs of authority are not limited to the close vicinity of the human carriers of authority. They stretch across the total material environment in which authority can be said to reside (from a room to the entire capital city).

8 There have been various useful efforts in the literature to approach the theme of meaningful, culturally significant elements in the material environment affecting social 
action. Only some of them are directly related to political authority. The following is a brief overview. In geography Gottmann was an early student of symbols that he considered important to stabilize human populations and counter the disruptive effects of circulation by providing them with a spatially specific identity. Early examples were religious stone monuments and crosses safeguarding people that had to pass crossroads that they considered dangerous. In the longer term flags, a sense of shared history, prevailing religious principles, classic authors and so on were added (Gottmann, 1952a p. 162, Gottmann, 1952b, pp. 512-519). The sets of symbols involved he called the iconography of a place bound population. Although Gottmann never developed this concept much further it played an important role in directing attention to culture and away from physical constraints in moulding and preserving the social life of a commonly settled population.

9 Art historians have since the 1920s developed interpretive ways of reading paintings and other pictorial art works based on the search for symbols in represented objects, arrangements and frames that could provide so far hidden extra meaning to these representations (Panofsky, 1962). Later on others, also geographers (Cosgrove \& Daniels, 1998) have widened the circle of objects that could lend themselves to such analyses including the architecture of buildings and designed landscapes (not only as pictures but also as segments of the real world). Iconography in this tradition stands for the empirical analysis of such symbol carrying objects in paintings and fragments of reality; iconology particularly aimed at questions of meaning of these symbols that show up in these images. It is important to recognize that the identification of symbols themselves may necessitate more or less subjective judgments.

Still another way to approach signs and symbols is through that part of language studies that developed into what is now usually called semiotics. It is a thriving field with a multitude of loose threads. In semiotics some signs are relatively unambiguously readable, others more circumspect. Compare the average readability of a text, a picture and the layout of an architectural ensemble but remember that also a seemingly unambiguous text may well have unexpected extra layers of meaning. The exceptional expression may have only one meaning, most will carry different meanings for different population segments. Compare the official and the nicknames of statues. In all cases of signs there is a sign bearer (signifier) and a related meaning (the signified following de Saussure's conceptualization). For the sake of interpretation, of minding the gap between signifier and signified there is a structure (so Lévi-Strauss), interpretant (Peirce) or valuation (de Saussure) needed to do the necessary translation work. This is much more elaborate and generally accepted in some cases than in others. Signs in this tradition are also called symbols when the relation signifier-signified is based on agreed rules (as in current language script). Iconic is in this connection a sign where there is a resemblance between signifier and signified (a decoration carrying the image of the current king thus referring to that authority).

11 The bearers of signs, the signifiers in semiotic terms, may be of different kinds. A recent introduction of anthropological work in the symbols of entire cities (Nas, 2011), where symbols are apparently identical with the concept of signs just used, mentions at least four types. First, cities as built environments can be explored for signs (material), then there are images and narratives on cities (discursive), also people -individuals or groupsrepresenting cities (iconic), and finally rituals, festivals and demonstrations loaded with meaningful signs (behavioural). There is considerable overlap between these categories. 
For our purposes it is important to consider that sign bearers within the built environment may have important discursive elements. Think of figurative decorations, evocative statues and lively frescoes. In addition icons conceptualized in this way and referring to historic figures will often be signified by means of discursive imagery in the city as built environment thus further mixing the categories. Finally iconic and behavioural sign bearers tend also to get mixed up in this way. A group performing a ceremony with signs referring to the city as a whole (behavioural) only differs from a set of figures that has become a sign for the city (iconic) in that the ceremony is a performance of a well established pattern while the figures have originally been involved in the creation of the sign. As such figures become part of history, a narrative is established perhaps reflected in a statue. The signifier now becomes primarily discursive but is also part of the material environment. That narrative can also be played out in a ceremony. The signifier now again becomes behavioural in these terms while also remaining discursive. It is a confusing classification.

This brief overview of current ways to approach the problem of meaning provision by signs or symbols shows a number of potentially useful entries and at the same time confusion by the use of concepts with similar meanings to some (sign, symbol, icon) while others stress additional attributions to introduce clear distinctions. As my main interest in this paper is in the actual symbolic function of the material context of public authorities to back up that authority I want to concentrate on that material context as sign bearer and to enumerate a number of entries as starting-points for further analysis.

\section{Classifying public authority's material environment}

13 The relevant material context for the backup of public authority should first be classified with respect to scale: primary space in which public authority is displayed (entrance, corridor, room) - individual building - architectonic ensemble which acts as the core of the political centre, if present - the political centre as a whole - capital city.

The scales of architectural ensemble and political centre are particularly diffuse. The level of spatial concentration of central government institutions in capital cities varies significantly (e.g. Van der Wusten, 2003) although most central functions (but not always their backoffices) share certain segments of capital cities. In some cases one architectural ensemble sets the tone even if it does not encompass everything, e.g. the core area of Washington D.C. already mentioned. In Paris despite a rich history in which the royal axis set the basic pattern of the entire capital for a long time - though not from the very start of centre formation - and central government is still spatially concentrated to a considerable extent, one decisive architectural ensemble that represents the site of French public authority is currently not to be found (Vale, 1992). Consequently there is an interest to look in this context for meaningful delimitations of the political centre as a whole and for the most important architectural ensemble if present.

Bearers of signs at these various scales can then be found:

- in the interiors of primary political spaces (the plan and design of Hitler's new chancellery at the Vossstrasse in Berlin by Speer opened in the late 1930s and completely destroyed at the end of the war was a textbook example, Balfour, 1990, 75-79)

- in the arrangements of material elements (buildings, surrounding landscape - green, water, passages - connecting boulevards/avenues/lanes, adjacent squares), decorations and 
ornaments, statues of architectural ensembles and political centres (the arrangements for Bonn as longtime provisional capital of West Germany and then of the Spreebogen and adjacent locations in Berlin have been extensively analyzed and commented from this perspective, e.g. Ehlers 1997; Siedler, 2000)

- in the positioning of architectural ensembles and political centres in the cityscapes of the capital (a main item in the planning of all new $20^{\text {th }}$ century capitals from Ankara onward (Gordon, 2006).

These signs turn into symbols to the extent that the rules relating the signifiers to the signified are explicit, generally agreed and accepted. This is not easy to determine and it probably varies considerably within the population to be taken into account. Physical plan and spatial arrangement may account for a general sense of atmosphere that induces the recognition of a certain level of authority. Individual items strategically positioned within these spaces additionally act as material indexical and iconic signs in the sense of general semiotics and thus underline existing narratives that ground and colour the sense of residential authority and provide it with its specific quality. Texts or single words and dates chiseled in stone add a discursive element to all these material signs often further elaborated by appropriate place names (e.g. central Washington avenues as connecting links named after federal states; the most central square in Paris' political centre named after a crucial collective virtue that public authority should in the end help produce: Place de la Concorde).

However, all intended and planned signs do not necessarily result in easily readable material environments. The entire built environment of public authorities has often been produced, maintained and occasionally transformed over long periods of time. In such cases major parts may have been realized in different style periods. Styles provide scripts in which notions of authority can be expressed. A variety of styles in one centre may hamper overall readibility. Think of the neo-Gothic character of the British parliament buildings and the neo-classicist features of nearby Whitehall, not to speak of its opposite number across the river, the neobaroque - now former - County Hall building and finally, somewhat downstream, the residence of the current successor of metropolitan government, the Greater London Authority, a flamboyant postmodern glassy signature building by global star architect Norman Foster. In addition, old styles but also newly introduced styles may be difficult to read for contemporary publics. This even undermines the idea that newly established capital cities with their political centres freshly constructed and installed necessarily function in the longer run as clear signs of the public authority that they accommodate. Think of the eventual readability of Brasilia, Chandigar and the current case of Kazachstan's Astana.

Still another occasion where the symbolic equipment of the material environment may be relevant to public authority is its functioning as a "natural" stage for the authority's performance in ceremonies. For this to happen longstanding features should become so much taken for granted that their originally intended messages are not quite lost but become appropriate background. They provide the selfevident scenery for public authority to highlight its own importance in ceremonial settings (e.g. think of the swearing in of new US presidents at the top of the stairs in front of the Capitol, the annual openings of parliaments by monarchs including a festive tour amidst crowds of spectators and the use of the Champs Elysées on the $14^{\text {th }}$ of July between Etoile and Place de la Concorde as a paradeground for the French armed forces including the air force overhead with a special place of honour for the president). 

he says, are in some countries nearly universally present, but hardly perceived. They are part of what he calls "banal nationalism" in which the nation is constantly flagged ensuring that the sense of nation remains present and can be mobilized if need be. Along comparable lines one could argue that the originally intended symbolic environment of public authority does not so much attract focused attention but assists in routinizing its acceptance. If only the link between signifier and signified can be resurrected at the moments when it is needed. This function of the material environment as a meaning loaded stage is in this perspective recurrently prompted by public ceremonies located at these places where public authorities perform in carefully choreographed fashion with the stage in full view.

Finally, we can think of the cultural function of public authorities' material environment through the images we obtain from the media. Our information on many of these places is not merely and sometimes not at all from direct observation, but through intermediaries and by means of pictures or textual descriptions. The web has immensely magnified the quantity of these information flows, but we were already well equipped to get acquainted with such sights on television, film and radio, in photo books and travel guides (from Karl Baedeker to Lonely Planet) and books by people who retold their adventures while underway (since the classics). That is to say, this has gone on for centuries on an ever larger scale. Mediated images result in selected and arranged portraits. Certain aspects are highlighted while others remain in the shadow. An extra layer of interpretation is added. The branding of cities - here capital cities - is largely executed by such images. In the context of our problem the question then arises how important images related to the function of the city as an accommodation of public authority are in this regard. Think for instance of the relative importance of the Reichstag image for Berlin compared to other highlights and of the extra twist that the images of Hofburg Palace in Vienna and Habsburg Castle in Buda give to this question as they are merely former vital parts of their respective national political centres.

21 In still another contribution to this literature from within geography (Monnet, 2006), it has been suggested to call this mediated imagery of city fragments iconic, taking the way the word "image" has been used in Orthodox religious art as a conceptual point of departure. Icons in that context are paintings on wood panels of sacred figures and objects. Representing revered beings and objects the question always arises if they can also be revered as picture. In the Eastern tradition producing an image of a revered person is allowed (but better not in three dimensions). The icons are very highly regarded but there is a hesitation to see them as sacred objects themselves. The icon is seen as a window that participates in the glory of what it represents. In the profane sphere of city representation the icons also function as windows opening up the vistas on the glories that await us when we come to visit. In many cases the public authorities and the political sphere more generally remain distant (think of Tour Eiffel) but not always (Big Ben, Washington's historic centre, Christiansborg in Copenhagen competing with the mermaid statue). Iconic here gets a different meaning from the one I mentioned earlier. Then it was the representation of the city by a person or group that could be perceived as such, here it is the representation of a central aspect of the city mediated by a different sign bearer just as the wooden panel carries (the image of) the sacred object. 


\section{Europe's state centres and capital cities as cases} different functions within the governing structures (legislature, executive, judicial system, head of state) but also to the differences of political opinion that will keep on being articulated in public life. So there is more chance to see historic political figures from different political corners to be portrayed on interior pictures and to be represented on statues in prominent public places. In autoritarian regimes there is an urge to present a uniform image always everywhere: the picture of the tyrant/despot/dictator himself or a sea of swastika's. But this should not be overemphasized. In Stalin's USSR there was a continuing confusion if the main figurative symbol of the regime should be its founder, 
the current boss, the proverbial cheerful progressing male and female labourer or the hammer and sickle as the two most useful instruments for making progress (see the successive intentions during the 1930s for the emblem on top of the planned but never realized gigantic Palace of the Soviets at the location of the destroyed and now rebuilt cathedral Christ the Saviour close to the Kreml (http://en.wikipedia.org/wiki/ Palace_of_the_Soviets, Van der Wusten, 2000).

For a cross-national comparison at some point in time it is indeed also relevant to consider each individual case's history as a political centre: long or short, continuous or with major ruptures. Long histories open up more possibilities for the mixing of aesthetic styles which necessitates the reading of the various symbolic languages and may well be confusing. But we have to keep in mind that some centres have preserved a dominant style over very long periods (e.g. the historic core of the Hague more or less preserving a stylistic unity that was only in the last decades seriously undermined by large departmental towers at the edge of the historic area (Van der Wusten, 1996). In addition, major political ruptures have not always resulted in huge discontinuities. The paradoxical case of the Moscow Kreml can be used as an example in this regard. It has to a large extent preserved its late medieval character to the present day despite anomalous additions like the Lenin Mausoleum and - inside the walled area - the State Kremlin Palace that result from the rupture in its political history. But part of this continuity is obviously due to its less prominent political role for more than two centuries as the csar and his government had moved to Saint Petersburg.

A further specification of the work done by Therborn is warranted. He primarily argues in terms of general didactic and representational responses by the higher classes (who also dominate the state) to a challenge of their hegemony by the lower orders of society and their need for support in foreign adventures from the side of these same categories of people. One can concentrate more specifically on the responses to these same challenges by way of a restructuring of the main organs of the state and the opening up of the polity to new popular categories. This is the time that parliaments got installed and their weight increased. How was this translated in terms of accommodations and what was the position of the parliament building in the locational pattern, the proportions and other features expressing prominence within the political centre and/or the core architectural ensemble?

Refurbishment and restructuring took place or were proposed in the existing British and Dutch parliaments. The Danish parliament became prestigiously located in the newly done former royal palace. New major building plans for parliaments were more or less reluctantly accepted in Germany, Austria and Hungary. After World War I a new parliament opened in newly founded Ireland in the former urban residence of the country's erstwhile largest landlord with the National Library and the National Museum at its sides, a true architectural ensemble. And a newly designed and built impressive parliament was erected in independent Finland as the start of a new political centre on a prominent location that however could for a long time not be further realized. These are just some examples (Van der Wusten, 2010).

\section{Further steps towards a comparative analysis}

29 At the outset of a comprehensive comparative analysis it will be important to realize that the cultural function of the material environment of public authorities has to be brought 
to life within the set of largely given natural qualities of the site: relief and soil, water surfaces and rivers. Site qualities enable some possibilities, e.g. to take advantage of relief and water contours to put buildings with certain functions in more prominent positions than others. The locations at or close to the water front of the original royal palaces in Copenhagen and Stockholm, London, Paris, Buda, Prague came about for various reasons: economic, military and also for reasons of prominence and splendour that could thus be displayed. In the longer term prominence and splendour became dominant, location and eventually restructured buildings continued to serve public authorities very well.

An intriguing field of further inquiry is the impact of religion on the formation of the material environment in support of public authority. In Rokkan's model of European nation- and state formation one basic cause of variation is religious diversity. Typologically summarized in Lutheran, Calvinist and Roman Catholic confessional families resulting from the era of Reformation in Western Europe spatially distributed in homogenous and mixed groupings, they should in a larger European perspective be complemented with an Orthodox tradition (that also knows considerable internal variation). Rokkan puts major emphasis on the resulting differences in cultural closure with homogenous Protestant countries easier and earlier mixing state formation and nation building while for Roman Catholics their supranational orientation remained a stumbling block in this respect. In religiously mixed areas religious cleavages could be mobilized in separate party formations before large working class parties had entered the political arena and wholesale secularization had deprived internal religious disputes of their former mobilizing potential.

It is important to remember that the church long dominated the public sphere in urban places before any specifically political institutions, not to speak of state organs, were installed there. What about the possible significance of religion for symbolism and staging in public space? Schillings work (2004) on cities with different dominant religions is interesting in this respect but he practically excludes the state from consideration. Three factors may be important: different uses of imagery in various religious traditions, the different division of labour in religious ritual, the different church-state relations resulting from the ever more dominant position of the state in public life.

While the Roman Catholic tradition thrives on the representation of sacred figures in images on paintings and in statues, Protestantism is far more reluctanct in this regard, particularly Calvinism. It is not by chance that an important stage of the Reformation consisted of iconoclastic riots focused on Roman Catholic shrines and churches. In the Orthodox tradition sacred figures are painted on icons but there are only images on flat surfaces and a reluctance to venerate them as sacred themselves. Do we in political contexts therefore see more abundant use of pictorial imagery in Roman Catholic parts of Europe and perhaps also where the Orthodox faith has long reigned supreme and more text in Protestant parts? Or has the prohibition of "graven images" in the religious sphere left no traces in the sphere of political public life?

What about staging? The Roman Catholic tradition is highly hierarchical with an ecclesiastical authority running supreme. Staging of collective ceremonies is formally organized, run by a distinct leadership echelon with trajectories and locations well identified and the collective nature of the occasion stressed. Protestantism has a far more individualized character with fewer collective events, but where individual participation then has its own intensity. In the Orthodox world view ritual is everything, known to everybody and a very collective event saturated with tradition. Hierarchy and central 
organization is perhaps less pronounced, but intensity can be very high. Do we see these differences in degree of formality, frequency and intensity reflected in the staging of political events and does the material environment then function differently under these different circumstances?

Historically, church-state relations belong to the most sensitive areas in which public order by public political authorities has to be established. This is because of the vital role that religion has long played. A differentiated political sphere exemplified by (in the end national) states has finally been superimposed on a social order that in cities had been largely dominated by ecclesiastical authority (Schilling, 2004). The accommodations of religious institutions with a public function then started to change hands to local civic authorities and in capital cities also to public authorities in charge of the state. Consequently, erstwhile monasteries, convents and buildings used for religious administration now became the accommodation for state functions in various countries (Italy, Portugal, Spain, Slovakia), while others changed hands and became locally administered schools and universities, orphanages, old people's homes. At a later stage church-state relations developed into more or less friendly stages of separation in which the order in the public sphere was basically a state responsibility. There was freedom of religious belief and to celebrate that belief in private with different negotiated incursions in the public sphere. In case of a state religion the church was allocated ceremonial functions and financial provisions could be regulated but there was no direct interference of the church in political matters and government. Under secularization church-state relations have become less and less contentious and urgent. The consequence of more intensive and friendly relations between church and state would provide, one might expect, a more fertile ground for the application of church traditions to state affairs in terms of ceremonial and symbolism, thus also for the construction of the material environment of state public authority.

A final suggestion for further work on this issue aims at the various aesthetic repertoires and building styles that have been developed over time. Generally speaking the impact of the classic tradition (primarily Roman and then also its Hellenic predecessor and its Greek example) have been extraordinarily influential in the official building tradition of Europe: see e.g. all of them united in the exterior and the original interior composition of Vienna's parliament building. Renaissance Rome restored by papal authority reconnected the rest of Europe to the classical tradition and so the accommodation of church authority set a powerful example for the following construction of political centres by its competitors in charge of territorial states for ultimate authority.

While the religious factor tends to result in variations across Europe within the broad confines of Christianity with a whiff of Islam at the southern edges, aesthetics applied in design, architecture, ornamentation and distinctive works of art tends to spread recognizably uniform for successive periods across Europe obviously with local varieties due to vernacular influences. Artists travelled, looked at pictures, talked to each other. Diplomatic contacts assured continuous information flows between capitals also communicating how those capitals looked. This gave the patrons of architectural construction views on what they should like and pursue. There were also diplomatartists: Rubens. These elite networks also spread styles including the symbolic scripts in which messages were moulded. Peter I invited European artists particularly from Italy to his new capital Petersburg in the early years of the $18^{\text {th }}$ century. French artists built and furnished important public buildings in The Hague in the mid $17^{\text {th }}$ century. French beaux 
arts designers and architects of the mid $19^{\text {th }}$ century built up the new government centers of newly independent countries of South Eastern Europe in Belgrade, Sofia and Bucharest after German classicist predecessors had redone the Greek capital downhill from the Akropolis and the Parthenon a bit earlier. In all these cases the religious divides that separated the different fragments of Europe during a considerable part of the state system's history were crossed. The question then arises what impressions these similarly shaped messages spread within these different religious territories left in the end with their publics.

If the knowledge of building styles tended to spread across major parts of Europe this does not imply that they were all represented in equal degree everywhere. As the example of South Eastern Europe already indicates, circumstances for realization differed per country per period. The overrepresentation of beaux arts architecture in South Eastern Europe does not indicate a special permanent preference for this aesthetic repertoire in this part of Europe, it is a consequence of special circumstances at this point in time: newly created independent states that require a new political centre. A similar situation explains the importance of Jugendstil and art deco particularly in interiors of public buildings in the political centres of the Baltic states and Norway and Finland: independence in the early $20^{\text {th }} \mathrm{c}$.

Building styles produce scripts through which intentions in a certain time period can be read. But scripts get out of fashion, lose their colour and attraction over time and are replaced by other scripts. It may well be that effortless understanding is replaced by misreadings in following generations. So far we know very little about these shifts in impact. However, it seems that the classicist repertoire has some permanence in terms of readibility. In slightly different ways it seems always to come back after a certain period of different preferences to take its place as indicator of the cardinal virtues of justice, temperance, prudence and fortitude that suit the front stage image of public authority very well in the end.

\section{BIBLIOGRAPHY}

BALFOUR A. (1990), Berlin. The politics of order 1737-1989, Rizzoli, New York.

BERTRAND M.-J. (1974), Géographie de l'administration. L'impact du pouvoir exécutif dans les capitales nationales, M.-Th. Génin, Paris.

BILLIG M. (1995), Banal nationalism, Sage, London.

COSGROVE D. \& S. DANIELS (eds.) (1998), The iconography of landscape. Essays on the symbolic representation, design and use of past environments, Cambridge University Press, Cambridge.

CLAVAL P. (2010), Les espaces de la politique, Colin, Paris.

EHLERS E. (ed.) (1997), Deutschland und Europa. Historische, politische und geographische Aspekten, Ferd. Dümmlers Verlag, Bonn, in particular : BORCHARD K., "Bonn -Von Provisorium über die Bundeshauptstadt zur Bundesstadt oder : von der Schwierigkeiten der baulichen und 
städtebaulichen Selbstdarstellung unseres Staates”, pp. 11-34 ; WÉKEL J., "Berlin auf dem Weg zur Bundeshauptstadt. Aufgaben, Ziele und Projekte der städtebauliche Entwicklung einer Metropole im Wandel", pp. 35-57.

GORDON D.L.A. (ed.) (2006), Planning twentieth century capitals, Routledge London.

GOTTMANN J. (1952a), “Geography and international relations”, World Politics, 4, 2, pp. 153-173.

GOTTMANN J. (1952b), “The political partitioning of our world: an attempt at analysis", World Politics, 4, 4, pp. 512-519.

MONNET J. (2006), “The geopolitics of visibility: urban icons in contemporary Mexico City” (in particular pp. 1-8), in ETHINGTON Ph.J. \& SCHWARZ V.R., "Atlas of urban icons: studies in urban visual history", Companion to Urban History, 33, 1, http://journals.cambridge.org/fulltext_content/ supplementary/Urban_Icons/atlas/content/07_monnet.htm

NAS P.J.M. (ed.) (2011), Cities full of symbols. A theory of urban space and culture, Leiden, University Press Amsterdam.

PANOFSKY E. (1962), Studies in Iconology: humanistic themes in the art of the Rennaisance, Harper \& Row, New York.

PARSONS T. (1971), The system of modern societies, Prentice Hall, Englewood Cliffs NJ.

ROKKAN S. (2000), Staat, Nation und Demokratie in Europa. Die Theorie Stein Rokkans aus seinen gesammelten Werken rekonstruiert und eingeleitet von Peter Flora, Suhrkamp, Frankfurt a.M.

SCHILLING H. (2004), "Calvinist and Catholic cities - urban architecture and ritual in confessional Europe", European Review, 12, 3, pp. 293-312.

SIEDLER W.J. (2000), Phoenix im Sand. Glanz und Elend der Hauptstadt, Propyläen Verlag, Berlin.

THERBORN G. (2002), "Monumental Europe: the national years. On the iconography of European capital cities", Housing, Theory \& Society, 19, pp. 26-47.

VALE L.J. (1992), Architecture, power and national identity, Yale University Press, New Haven.

WUSTEN H. van der (2000), "Dictators and their capital cities: Moscow and Berlin in the 1930s", GeoJournal, 52, 4, pp. 339-344.

WUSTEN H. van der (2003), "Keuze en effect van vestigingsplaatsen ten behoeve van de politieke functie”, in CORTIE C. , DROOGLEEVER FORTUIJN J., WAGENAAR M. (eds.), Stad en land. Over bewoners en woonmilieus, Aksant, Amsterdam, pp. 160-173.

WUSTEN H. van der (2004), "Public authority in European capitals: a map of governance, an album with symbols", European Review, 12, 2, pp. 143-158.

WUSTEN H. van der (2006), “'Legal capital of the world': political center-formation in The Hague”, Tijdschrift voor Economische en Sociale Geografie, TESG 97, 3, pp. 253-266.

WUSTEN H. van der (2010), What parliamentary buildings say. A comparative study of material symbolism in European policies, Paper presented at AAG Annual conference, Washington D.C., April.

WUSTEN H. van der (2012), "Political global cities”, in DERUDDER B., HOYLER M., TAYLOR P.J. \& WITLOX F. (eds.), International Handbook of Globalization and World Cities, Edward Elgar, Cheltenham, pp. 40-481.

http://en.wikipedia.org/wiki/Palace_of_the_Soviets 


\section{ABSTRACTS}

The paper starts from the concept of political centre formation as a necessary and continuing process in the emergence and maintenance of larger differentiated societies. Accommodations of public authorities spatially concentrate within cities, mostly called capitals. The paper is about the ways in which the built environment in which public authorities operate, supports them symbolically. Introductory sections about the use of symbols, signs and icons in this context are followed by sections that take the political centres in the European state system as a relevant example and indicate ways to study this question in a comparative fashion.

L'article part du concept de formation d'un centre politique comme d'un processus nécessaire et ininterrompu dans l'émergence et le maintien de grandes sociétés différenciées. Les implantations des autorités publiques sont concentrées dans les villes, principalement des capitales. L'article examine les façons dont l'environnement bâti dans lequel ces autorités opèrent les soutient symboliquement. Les premières parties sont consacrées à l'usage de symboles, signes et icônes dans ce contexte tandis que les suivantes prennent les centres politiques dans le système étatique européen comme un exemple pertinent et indiquent des pistes pour étudier cette question de manière comparative.

\section{INDEX}

Mots-clés: centre politique, capitale, symbole, signe, icône, système étatique européen

Keywords: political centre, capital city, symbol, sign, icon, European state system

\section{AUTHOR}

\section{HERMAN VAN DER WUSTEN}

Dept. of Geography, Planning and International Development Studies, University of Amsterdam, h.h.vanderwusten@uva.nl 